\author{
흑염소의 거세시기가 발육, 육질 및 지방산조성에 미치는 영향 \\ 최순호·김상우 · 황보순* · 최창용·김진형 \\ 농촌진흥청 국립축산과학원
}

\title{
Effects of the Castration Time on Growth Performance, Meat Quality and Fatty Acid Profiles of Korean Black Goats
}

\author{
Sun Ho Choi, Sang Woo Kim, Soon Hwangbo*, Chang Yong Choe and Jin Hyoung Kim \\ National Institute of Animal Science, RDA.
}

\begin{abstract}
A study was conducted to examine the effect of the castration time on growth, meat quality and fatty acid composition of Korean black goats. Forty five male kids were divided into five groups, including control (without castration) and four groups with the kids castrated at $0.5,3,5$ and 7 months of age, respectively. Average daily body weight gain (ADG) for control was significantly $(\mathrm{P}<0.05)$ higher than the castrated groups. ADG did not differ between the castrated groups. The ADG of the male kids castrated at 3 and 5 months of age tended to be higher than the other castrated groups. Dressing percentage for 0.5 months-castrated group was higher than 7 months-castrated group. Retail cut percentages for control was higher $(\mathrm{P}<0.05)$ than others, but the retail cut percentages did not differ between the castrated groups. Compared with control, higher fat percentages of carcasses appeared in the castrated groups $(\mathrm{P}<0.05)$. The fat percentages gradually increased in earlier castrated animals. As castrated earlier, moisture contents tended to decrease, whereas crude protein and fat contents tended to increase. The different castration time did not affect physical properties of goat meat (shear force, cooking loss, and water holding capacity). Results from panel tests showed that juiciness or tenderness of meats for 5 months-castrated group tended to be higher than those for the other groups. The flavor of meatfor 7-months castrated group appeared to be more favorable compared with 0.5- or 3-months castrated groups $(\mathrm{P}<0.05)$. The proportion of saturated fatty acid in meat washigher for 5 -months castrated group and lower for 3 -months castrated group as compared to the other castrated groups, whereas the proportion of unsaturated fatty acid was vice versa $(\mathrm{P}<0.05)$. Mono-unsaturated fatty acid contents did not differ between thecastrated groups. Present results indicatedthat castration at 3 or 5 months of age increased growth performance and meat quality of Korean black goats.
\end{abstract}

(Key words : Korean black goat, Castration, Growth, Meat quality, Fatty acid)

\section{서 론}

웰빙, 건강식품에 대한 소비자의 인지도가 증가하면서 흑염소의 사육형태가 전업화 규모로 변화되고 있으며 소비도 증가 추세에 있 다. 흑염소는 주로 약용위주로 소비되어 왔으나 근래 흑염소전문 음식점이 성행함에 따라 육용위주의 소비가 크게 증가되고 있다. 흑염소고기는 일반 육류보다 특이취가 강하여 음식으로 섭취하는데 상당한 거부감이 있으며 피하와 근육내지방량이 일반 육류에 비해 적기 때문에 다즙성과 연도가 낮은 단점을 갖고 있다(Banskalieva 등, 2000). 이러한 단점을 개선하기 위해 거세에 대한 연구가 수행 되고 있으며 국내에서는 흑염소 거세가 비거세보다 발육과 육량이 낮고 체지방과 뼈 함량의 증가와 고기의 향미, 연도가 개선되었다 (서 등, 1983; 최 등, 2000)고 하였으며, 국외에서는 염소의 거세
는 특이취를 제거(Louca 등, 1977)할뿐만 아니라 피하와 근내 지 방량의 증가로 다즙성과 연도를 개선함으로써 육질을 향상시킬 수 있는 장점을 가지고 있다 (Mahgoup 등, 2002)고 하였다. 염소의 거세가 성장에 미치는 영향은 연구자에 따라 상반된 결과들이 다양 하게 보고되었고(Louca 등, 1977; Sing 등, 1996) 도체의 지방함 량의 증가와 육질개선 효과가 있었다(Tahir 등, 1994). 거세를 함 으로써 염소고기의 지방산조성은 포화지방산 비율은 낮고 단가불포 화지방산 비율이 더 높았으며(Werdi Pratiwi 등, 2005), 이러한 지방산 조성의 차이는 염소의 품종과 도축시 체중 그리고 거세유무 에 따라 상당한 차이가 있었다(Madruga 등, 2001; Tshabalala 등, 2003). 대부분 농가가 흑염소의 거세를 실시하고 있으나 거세 시기에 대한 연구결과가 전무하여 농가에서 많은 시행착오와 현장 애로를 겪고 있어 이에 대한 연구가 요구되고 있다. 따라서 본 시

* Corresponding author: Soon Hwangbo, National Institute of Animal Science, RDA. Cheonan, 330-801, Korea. Tel: (041) 580-6770, E-mail: simona@rda.go.kr 
험은 흑염소의 거세시기가 발육, 육질 및 지방산조성에 미치는 효 과를 구명하고자 수행하였다.

\section{재료 및 방법}

\section{1. 공시가축 및 시험장소}

본 시험에 이용된 공시가축은 흑염소교잡종 (재래종 $\times$ 누비안종 수컷 육성축 45 두이며 처리구별로 각각 9두씩 공시하였고 시험기 간은 2008년 3월 21일부터 2008년 10월 31일까지 225일간 국립 축산과학원 가축유전자원시험장에서 수행하였다.

\section{2. 공시사료 및 시험축의 사양관리}

시험사료의 일반조성분은 Table 1 과 같으며 농후사료는 $\mathrm{CP}$ $14.5 \%$ 수준의 시판중인 염소전용배합사료를 이용하였다. 시험축은 모든 처리구를 3 개월령에 동시에 배치하였고, 거세는 생후 15 일령, 3 개월, 5 개월, 7 개월령에 각각 실시하였다. 생후 15 일령에 거세한 개체들은 포유를 하고 있어 3 개월령에 이유한 후 처리구에 배치하 여 다른 처리구와 동일하게 사양관리를 하였으며 대조구로 비거세

Table 1. Ingredients and chemical composition of experimental diets

\begin{tabular}{lc}
\hline Item & \% of DM \\
\hline \hline Ingredients & 13.0 \\
Corn & 8.0 \\
Wheat & 19.4 \\
Wheat bran & 3.0 \\
Tapioca & 15.0 \\
corn gluten feed & 15.0 \\
Coconut meal & 3.2 \\
Canola meal & 14.47 \\
Palm kernel meal & 3.5 \\
Molasses & 1.4 \\
Limestone & 0.5 \\
Salt & 0.08 \\
Vitamin premix & 0.15 \\
Mineral premix & 100 \\
Total & \\
\hline Chemical composition & 10.8 \\
Moisture (\%) & 14.5 \\
Crude protein (\%) & 3.4 \\
Crude fat (\%) & 9.6 \\
Crude fiber (\%) & 6.6 \\
Crude ash (\%) & 68.0 \\
TDN (\%) &
\end{tabular}

구를 배치하였다. 시험축의 사양관리는 $1.8 \mathrm{~m} \times 1.8 \mathrm{~m}$ 크기의 케이 지에 3 두씩 수용하여 군집관리를 하였으며 배합사료는 시험개시 15 일전부터 체중의 $1.5 \%$ 부터 급여하여 점차 증량하였고 시험개 시부터는 오전 9 시경에 두당 체중의 $2.0 \%$ 를 급여하였으며 볏짚은 자유채식토록 하였다. 물은 급수조를 이용하여 신선한 물을 자유롭 게 먹을 수 있도록 하였다.

\section{3. 체중 및 사료섭취량}

체중조사는 시험개시일에 측정한 체중을 개시체중으로 하여 시험 종료시까지 30 일 간격으로 오전 공복시에 측정하였으며 증체량은 종료시 체중에서 개시체중을 뺀 값으로 구하였다. 사료섭취량은 사 료급여량을 측정하여 급여한 후 다음날 사료급여 전에 잔량을 측정 하여 급여량에서 잔량을 제한 값을 사료섭취량으로 계산하였다. 사 료요구율은 사료섭취량을 증체량으로 나누어 계산하였다.

\section{4. 도체 및 육질조사}

도체조사는 시험종료 후 각 처리구별로 체중이 비슷한 시험축 3 두씩을 선발하여 국립축산과학원 축산물이용과 육가공연구실에서 박피처리로 도축하여 $5^{\circ} \mathrm{C}$ 에서 24 시간 냉장시킨 후 발골하여 도체 중, 정육중, 뼈, 지방의 중량을 전자저울을 이용하여 측정하였고, 육질은 처리구당 3 두씩 3 반복으로 9점의 시료를 등심과 채끝에서 채취하여 등심근은 일반조성분 그리고 채끝은 전단력을 조사하는데 이용하였다. 일반조성분은 A.O.A.C. (1990) 방법에 준하여 분석하 였으며, 가열감량, 전단력 (Warner-Bratzler shear meter, G-R Elec. $\mathrm{Mfg}$. Co. USA)을 조사하였고, 관능검사는 검사요원 10 명을 무작 위로 차출하여 처리별로 다즙성, 연도, 향미에 대하여 기호도 6점 만점으로 하여 조사하였다.

\section{5 지방산 조성}

지방산 분석은 Morrison과 Smith(1967)의 방법을 따라 등심부 위에서 세절육 $50 \mathrm{~g}$ 에 $\mathrm{MeOH}:$ Chloroform=1:2로 혼합한 용액 (Folch solvent)(Folch 등, 1957)을 넣고 혼합한 다음 Homogenizer $(2,500 \mathrm{rpm})$ 로 마쇄하여 지질을 추출하였다. 추출된 지질을 증발농축기로 지방만 분리한 후 $0.5 \mathrm{~N}-\mathrm{NaOH}(2 \mathrm{~g} N a \mathrm{Nah} / 100 \mathrm{ml}$ methanol) 용액을 혼합하고 가열하여 냉각시켰다. 그리고 $\mathrm{BF}_{3}$ methanol을 넣고 가열한 후 heptane과 $\mathrm{NaCl}$ 포화용액을 혼합한

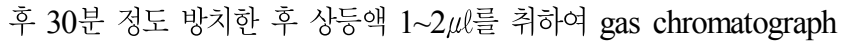
$(\mathrm{GC})$ 에서 지방산을 분석하였다.

\section{6. 통계분석}

통계분석은 SAS (Statistical Analysis System Institute Inc. 1991) package를 이용하여 분석하였으며, 처리간 유의성은 Duncan's multiple range test 방법을 이용하여 검정하였다. 


\section{결과 및 고찰}

\section{1. 증체량 및 사료섭취량}

흑염소의 거세시기를 각각 달리하여 조사한 결과 증체량 및 사료 섭취량은 Table 2와 같다.

거세시기별 일당증체량은 $56.8 \sim 62.5 \mathrm{~g}$ 으로 처리구 간에 차이는 없었으나 3 5개월령 거세가 다소 높은 경향이었다. 거세와 비거세 간에는 비거세가 $71.0 \mathrm{~g}$ 으로 거세보다 높았으며 $(\mathrm{P}<0.05)$ 거세가 비 거세보다 증체량이 $17.5 \sim 25.0 \%$ 저하되는 것으로 나타났다. 이러한 원인은 거세에 의한 스트레스와 체내 성장호르몬의 농도와 연관이 있는 것으로 사료된다.

서 (1983)는 한국재래산양에서 거세가 비거세보다 증체량이 26.2 $\%$ 저하되었고, Koyuncu 등 (2007)은 터키 모용종 염소에서 거세 를 함으로써 비거세보다 증체량이 $24.5 \%$ 저하되었다고 하여 본 시 험결과와 일치하였다. 한편 Haddad 등(2005)은 Awassi와 Karakas
면양에서 거세와 비거세간의 일당증체량의 차이가 없었다고 하여 본 시험결과와 다소 차이는 있었지만 이는 품종과 사양관리에 따른 성장의 차이로 생각된다. 1 일 건물사료섭취량은 거세시기별로 680 $700 \mathrm{~g}$ 으로 비거세구 $730 \mathrm{~g}$ 보다 약간 낮은 경향이었고 증체 $\mathrm{g}$ 당 사 료요구율은 3 개월령 거세가 다소 낮은 경향이었고 비거세는 10.3 으로 거세보다 낮은 경향이었다.

\section{2. 도체특성}

처리구별 도체특성은 Table 3 와 같다. 거세시기별 도체율은 48.1 54.2\%로 15 일령 거세가 7개월령 거세보다 높았고 $(\mathrm{P}<0.05)$ 거세시기가 빠를수록 증가하는 경향이었다. 비거세는 $53.16 \%$ 로 7 개월령 거세보다 높았다 $(\mathrm{P}<0.05)$. 한편 Allan과 Holst $(1989)$ 는 생체중 $20 \mathrm{~kg}$ 에서 도축하였을 때 도체율은 거세가 $48.4 \%$ 로 비거 세 44.4\% 보다 높았고, Koyuncu 등 (2007)은 터키 모용종 염소에 서 거세가 비거세보다 도체율이 높았다고 보고하여 다소 차이가 있

Table 2. Effects of the castration time on body weight gain and dry matter intake of Korean black goat

\begin{tabular}{|c|c|c|c|c|c|}
\hline \multirow{2}{*}{ Item } & \multicolumn{4}{|c|}{ Castration time } & \multirow{2}{*}{ intact male } \\
\hline & at 15 days & at 3 month & at 5 month & at 7 month & \\
\hline Initial body weight (kg) & $14.86 \pm 0.20$ & $15.05 \pm 0.49$ & $15.49 \pm 0.42$ & $15.50 \pm 0.80$ & $15.42 \pm 0.17$ \\
\hline Final body weight $(\mathrm{kg})$ & $27.63 \pm 0.95$ & $29.11 \pm 1.66$ & $29.12 \pm 1.33$ & $28.58 \pm 0.56$ & $31.39 \pm 0.37$ \\
\hline Total gain (kg) & $12.77 \pm 1.13$ & $14.06 \pm 1.75$ & $13.63 \pm 0.98$ & $13.08 \pm 0.50$ & $15.97 \pm 0.49$ \\
\hline ADG (g/day) & $56.77 \pm 5.02^{b}$ & $62.50 \pm 7.79^{b}$ & $60.58 \pm 4.37^{b}$ & $58.15 \pm 1.99^{\mathrm{b}}$ & $70.99 \pm 2.18^{\mathrm{a}}$ \\
\hline TDMI (g/day) & 680 & 680 & 700 & 700 & 730 \\
\hline - concentrated & 400 & 400 & 400 & 400 & 400 \\
\hline - straw & 280 & 280 & 300 & 300 & 330 \\
\hline Feed conversion ratio & 11.98 & 10.88 & 11.55 & 12.04 & 10.28 \\
\hline TDMI/ADG (g/g) & & & & & \\
\hline
\end{tabular}

ADG : Average daily gain. TDMI: Total dry matter intake.

Data are expressed as means \pm SD.

${ }^{a, b}$ Values with different superscripts within same rows are significantly different $(\mathrm{p}<0.05)$.

Table 3. Effects of the castration time on carcass characteristics of Korean black goat

\begin{tabular}{|c|c|c|c|c|c|}
\hline \multirow{2}{*}{ Item } & \multicolumn{4}{|c|}{ Castration time } & \multirow{2}{*}{ intact male } \\
\hline & at 15 days & at 3 month & at 5 month & at 7 month & \\
\hline Slaughter weight (kg) & $27.00 \pm 1.41$ & $27.50 \pm 0.71$ & $28.00 \pm 1.41$ & $27.50 \pm 0.71$ & $27.50 \pm 0.71$ \\
\hline Cold carcass weight $(\mathrm{kg})$ & $14.63 \pm 0.60^{\mathrm{a}}$ & $14.13 \pm 0.32^{\mathrm{ab}}$ & $14.13 \pm 0.04^{\mathrm{ab}}$ & $13.23 \pm 0.11^{\mathrm{b}}$ & $14.63 \pm 0.74^{\mathrm{a}}$ \\
\hline Dressing percentage $(\%)$ & $54.18 \pm 0.61^{\mathrm{a}}$ & $51.40 \pm 2.48^{\mathrm{ab}}$ & $50.51 \pm 2.68^{\mathrm{ab}}$ & $48.10 \pm 0.85^{\mathrm{b}}$ & $53.16 \pm 1.33^{\mathrm{a}}$ \\
\hline Meat weight (kg) & $7.65 \pm 0.68^{\mathrm{b}}$ & $7.08 \pm 0.13^{b}$ & $7.53 \pm 0.04^{b}$ & $6.94 \pm 0.21^{\mathrm{b}}$ & $8.95 \pm 0.53^{\mathrm{a}}$ \\
\hline Meat percentage $(\%)$ & $52.26 \pm 2.49^{\mathrm{b}}$ & $50.13 \pm 0.23^{\mathrm{b}}$ & $53.27 \pm 0.38^{\mathrm{b}}$ & $52.43 \pm 1.13^{\mathrm{b}}$ & $61.15 \pm 0.52^{\mathrm{a}}$ \\
\hline Fat percentage $(\%)$ & $18.84 \pm 1.84^{\mathrm{a}}$ & $18.20 \pm 2.54^{\mathrm{ab}}$ & $16.00 \pm 0.54^{\mathrm{ab}}$ & $14.60 \pm 0.76^{\mathrm{b}}$ & $7.39 \pm 0.28^{\mathrm{c}}$ \\
\hline Bone percentage $(\%)$ & $18.02 \pm 0.31^{\mathrm{c}}$ & $20.79 \pm 1.42^{\mathrm{ab}}$ & $20.57 \pm 0.50^{\mathrm{ab}}$ & $22.04 \pm 0.12^{\mathrm{a}}$ & $19.64 \pm 0.51^{\mathrm{b}}$ \\
\hline
\end{tabular}

$\overline{a, b, c}$ Values with different superscripts within same rows are significantly different $(\mathrm{p}<0.05)$. 
었다. 이러한 차이는 염소의 품종, 연령, 사양관리, 도축체중에 따 른 차이로 사료된다.

정육율은 거세시기별로 50.1 53.3\%로 차이가 없었으나 거세와 비거세간에는 비거세가 $61.1 \%$ 로 거세보다 높았다 $(\mathrm{P}<0.05)$. 서 등 (1983)은 한국 흑염소에 있어서 정육비율은 비거세 및 거세가 각 각 $68.4 \%, 63.0 \%$ 로서 비거세가 높았다고 하였다. 지방율은 15 일 령 거세가 $18.8 \%$ 로 가장 높았으며 $(\mathrm{P}<0.05)$, 비거세는 $7.39 \%$ 로 거세보다 낮았다 $(\mathrm{P}<0.05)$. 뼈율은 7개월령 거세가 가장 높았고 $(\mathrm{P}<0.05)$, 비거세는 15 일령 거세보다 높았으나 7 개월령 거세보다 낮았다 $(\mathrm{P}<0.05)$.

이상의 도체특성을 종합적으로 고려하면 7개월령 거세를 제외하 고는 거세와 비거세간에 도체율의 차이는 없었으며 정육율은 거세 가 비거세보다 낮았고 $(\mathrm{P}<0.05)$, 지방율은 반대로 거세가 비거세보 다 높았다 $(\mathrm{P}<0.05)$. 거세를 하게 되면 비거세보다 지방량의 증가 로 정육량이 감소하게 되는데 이러한 이유는 거세를 실시함으로써 근육조직의 축적에 관여하는 질소대사에 있어 호르몬의 중재역할의 차이가 있기 때문이며 (Galbraith 둥, 1978) 또한 체내 성장호르 몬과 대사물질 조절 및 농도에 연관이 있는 것으로 사료된다.

\section{3. 육질특성}

처리구별 흑염소고기의 일반조성분은 Table 4 와 같다. 흑염소고 기의 수분 함량은 거세시기가 빠를수록 감소하는 경향이었고 비거 세는 15 일령 거세보다 높았다 $(\mathrm{P}<0.05)$. 조단백질, 조지방 함량은
거세시기가 빠를수록 증가하는 경향이었고, 거세가 비거세보다 높 은 경향이었으며 15 일령 거세는 조단백질 함량이 비거세보다 높았 다 $(\mathrm{P}<0.05)$. 한편 Madruga 등 (1999)은 염소고기의 일반조성분에 있어서 거세한 염소고기가 비거세보다 수분과 단백질 함량은 다소 낮고 지방과 회분 함량은 높은 경향이었다고 하여 본 시험결과와 수분, 지방 함량은 일치하였으나 단백질, 회분 함량은 다소 차이가 있었다. 최 등 (2000)은 체중 $20 \mathrm{~kg}$ 내외인 흑염소고기의 수분 함량 은 $76.04 \%$, 조단백질 $19.83 \%$, 조지방 $1.64 \%$, 조회분 $1.11 \%$ 이었 고, Babiker 등 (1990)은 염소고기의 수분 함량은 $75.04 \%$, 단백질 $20.5 \%$, 지방 $2.8 \%$, 회분 $1.23 \%$ 이었다고 하여 본 시험 결과와 비 슷하였다.

육질의 물리적 특성은 Table 5와 같으며 전단력, 가열감량 그리 고 보수력은 거세시기별, 거세와 비거세간에 유의적인 차이는 없었 으나 5개월령과 7 개월령 거세가 다른 처리구보다 전단력이 다소 낮은 경향이었다. 관능검사결과에서는 다즙성, 연도 그리고 향미는 5 개월령과 7 개월령 거세가 다소 우수하였고, 7 개월령 거세는 15 일 령, 3 개월령 거세보다 향미가 우수하였다 $(\mathrm{P}<0.05)$.

\section{4. 지방산 조성}

처리구별 흑염소고기의 지방산 조성은 Table 6과 같다. 지방산 함량은 $\mathrm{C} 18: \ln 9$ (Oleic acid) 48.0 52.8\%로 가장 많았고 다음으 로 $\mathrm{C} 16: 0$ (Palmitic acid) 22.1 23.9\%, C18:0 (Stearic acid) 15.3 $\sim 19.5 \%$ 순으로 나타났다. $\mathrm{C} 18: 0$ 은 거세시기별로는 차이가 없었으

Table 4. Effect of the castration time on chemical compositions of Korean black goat meat

\begin{tabular}{|c|c|c|c|c|c|}
\hline \multirow{2}{*}{ Item } & \multicolumn{4}{|c|}{ Castration time } & \multirow{2}{*}{ intact male } \\
\hline & at 15 days & at 3 month & at 5 month & at 7 month & \\
\hline Moisture (\%) & $74.22 \pm 0.99^{b}$ & $75.54 \pm 1.31^{\mathrm{ab}}$ & $74.90 \pm 0.35^{\mathrm{ab}}$ & $74.92 \pm 0.39^{\mathrm{ab}}$ & $76.83 \pm 0.49^{\mathrm{a}}$ \\
\hline Crude protein $(\%)$ & $20.45 \pm 2.47^{\mathrm{a}}$ & $17.52 \pm 0.40^{\mathrm{ab}}$ & $17.58 \pm 0.45^{\mathrm{ab}}$ & $17.72 \pm 0.06^{\mathrm{ab}}$ & $17.23 \pm 0.08^{\mathrm{b}}$ \\
\hline Crude fat $(\%)$ & $2.39 \pm 1.51$ & $1.87 \pm 1.15$ & $2.31 \pm 0.11$ & $2.01 \pm 0.39$ & $0.80 \pm 0.01$ \\
\hline Crude ash (\%) & $0.93 \pm 0.16$ & $0.99 \pm 0.02$ & $0.93 \pm 0.12$ & $0.89 \pm 0.15$ & $1.12 \pm 0.25$ \\
\hline
\end{tabular}

${ }^{a, b}$ Values with different superscripts within same rows are significantly different $(\mathrm{p}<0.05)$.

Table 5. Effect of the castration time on physical properties of Korean black goat meat

\begin{tabular}{lccccc}
\hline \multirow{2}{*}{ Item } & \multicolumn{2}{c}{ Castrated } & \multirow{2}{*}{ intact male } \\
\cline { 2 - 5 } & at 15 days & at 3 month & at 5 month & at 7 month & $3.79 \pm 0.11$ \\
\hline \hline Shear force $\left(\mathrm{kg} / \mathrm{cm}^{2}\right)$ & $2.67 \pm 0.25$ & $2.58 \pm 1.76$ & $2.33 \pm 0.78$ & $2.20 \pm 0.55$ & $33.10 \pm 0.28$ \\
Cooking loss $(\%)$ & $26.22 \pm 0.66$ & $21.92 \pm 11.09$ & $26.05 \pm 5.59$ & $26.99 \pm 2.98$ & $56.68 \pm 0.33$ \\
Water holding capacity (\%) & $57.63 \pm 3.14$ & $56.43 \pm 2.10$ & $58.17 \pm 0.43$ & $59.70 \pm 0.24$ & $4.50 \pm 0.28$ \\
Juiciness & $4.55 \pm 0.35$ & $4.35 \pm 0.21$ & $4.85 \pm 0.49$ & $4.60 \pm 0.14$ & $4.35 \pm 0.21$ \\
Tenderness & $4.95 \pm 0.35$ & $4.25 \pm 0.35$ & $5.45 \pm 0.35$ & $4.60 \pm 0.14$ & $4.25 \pm 0.07^{\mathrm{abc}}$ \\
Flavour & $4.15 \pm 0.21^{\mathrm{bc}}$ & $3.85 \pm 0.49^{\mathrm{c}}$ & $4.70 \pm 0.00^{\mathrm{ab}}$ & $4.90 \pm 0.14^{\mathrm{a}}$ & 4.28 \\
\hline
\end{tabular}

\footnotetext{
a,b Values with different superscripts within same rows are significantly different $(\mathrm{P}<0.05)$.
} 
Table 6. Effect of the castration time on profiles of fatty acids of Korean black goat meat

\begin{tabular}{|c|c|c|c|c|c|}
\hline \multirow{2}{*}{ Item } & \multicolumn{4}{|c|}{ Castration ages } & \multirow{2}{*}{ intact male } \\
\hline & at 15 days & at 3 month & at 5 month & at 7 month & \\
\hline C14:0 & $2.58 \pm 0.55$ & $2.07 \pm 0.24$ & $2.57 \pm 0.43$ & $2.10 \pm 0.28$ & $2.50 \pm 0.41$ \\
\hline C16:0 & $23.98 \pm 1.95$ & $23.04 \pm 1.23$ & $23.78 \pm 1.97$ & $22.38 \pm 1.33$ & $22.15 \pm 0.68$ \\
\hline $\mathrm{C} 16: \ln 7$ & $2.45 \pm 0.22$ & $2.48 \pm 0.13$ & $2.42 \pm 0.22$ & $2.27 \pm 0.24$ & $2.36 \pm 0.06$ \\
\hline C18:0 & $16.76 \pm 1.21^{\mathrm{bc}}$ & $15.29 \pm 0.38^{\mathrm{c}}$ & $18.09 \pm 1.42^{\mathrm{ab}}$ & $17.24 \pm 1.63^{\mathrm{abc}}$ & $19.49 \pm 1.41^{\mathrm{a}}$ \\
\hline C18:1n9 & $49.85 \pm 2.82^{\mathrm{ab}}$ & $52.84 \pm 1.48^{\mathrm{a}}$ & $48.99 \pm 0.45^{\mathrm{ab}}$ & $51.84 \pm 1.79^{\mathrm{ab}}$ & $47.96 \pm 3.34^{b}$ \\
\hline $\mathrm{C} 18: \ln 7$ & $0.00 \pm 0.00$ & $0.02 \pm 0.03$ & $0.00 \pm 0.00$ & $0.01 \pm 0.02$ & $0.02 \pm 0.03$ \\
\hline C18:2n6 & $2.48 \pm 0.36$ & $2.68 \pm 0.33$ & $2.55 \pm 0.77$ & $2.84 \pm 0.68$ & $3.58 \pm 1.08$ \\
\hline C18:3n6 & $0.10 \pm 0.00^{\mathrm{bc}}$ & $0.09 \pm 0.00^{\mathrm{c}}$ & $0.09 \pm 0.02^{\mathrm{bc}}$ & $0.11 \pm 0.01^{\mathrm{ab}}$ & $0.13 \pm 0.02^{\mathrm{a}}$ \\
\hline C18:3n3 & $0.08 \pm 0.01$ & $0.08 \pm 0.01$ & $0.08 \pm 0.02$ & $0.06 \pm 0.04$ & $0.08 \pm 0.04$ \\
\hline $\mathrm{C} 20: \ln 9$ & $0.10 \pm 0.01$ & $0.15 \pm 0.05$ & $0.09 \pm 0.03$ & $0.13 \pm 0.07$ & $0.14 \pm 0.03$ \\
\hline C20:4n6 & $1.63 \pm 0.01$ & $1.29 \pm 0.15$ & $1.34 \pm 0.32$ & $1.02 \pm 0.86$ & $1.62 \pm 0.47$ \\
\hline Total & $100.00 \pm 0.00$ & $100.00 \pm 0.00$ & $100.00 \pm 0.00$ & $100.00 \pm 0.00$ & $100.00 \pm 0.00$ \\
\hline SFA & $43.31 \pm 2.39^{\mathrm{ab}}$ & $40.39 \pm 1.10^{b}$ & $44.44 \pm 1.61^{\mathrm{a}}$ & $41.73 \pm 2.67^{\mathrm{ab}}$ & $44.13 \pm 2.43^{\mathrm{ab}}$ \\
\hline USFA & $56.69 \pm 2.39^{\mathrm{ab}}$ & $59.61 \pm 1.10^{\mathrm{a}}$ & $55.56 \pm 1.61^{\mathrm{b}}$ & $58.27 \pm 2.67^{\mathrm{ab}}$ & $55.87 \pm 2.43^{\mathrm{ab}}$ \\
\hline mono & $52.40 \pm 2.73^{\mathrm{ab}}$ & $55.48 \pm 1.34^{\mathrm{a}}$ & $51.50 \pm 0.52^{\mathrm{ab}}$ & $54.25 \pm 2.10^{\mathrm{ab}}$ & $50.47 \pm 3.25^{\mathrm{b}}$ \\
\hline poly & $4.29 \pm 0.34$ & $4.13 \pm 0.29$ & $4.06 \pm 1.13$ & $4.02 \pm 1.38$ & $5.40 \pm 1.49$ \\
\hline
\end{tabular}

a,b,c Values with different superscripts within same rows are significantly different $(\mathrm{p}<0.05)$.

나 비거세가 15 일령과 3 개월령 거세보다 높았다 $(\mathrm{P}<0.05)$. $\mathrm{C} 18$ : $1 \mathrm{n} 9$ 는 3 개월령 거세가 다소 높은 경향이었고 거세가 비거세보다 높은 경향이었다. 한편 $\mathrm{C} 18: 3 \mathrm{n} 6$ 은 비거세가 15 일령, 3 개월령 그 리고 5 개월령 거세보다 높았으며 $(\mathrm{P}<0.05)$ 7개월령 거세와는 비슷 하였다.

총 지방산 중에서 포화지방산 함량은 5 개월령 거세가 $44.4 \%$ 로 가장 높았고 3 개월령 거세가 가장 낮았다 $(\mathrm{P}<0.05)$. 불포화지방산 함량은 반대로 3 개월령 거세가 $59.6 \%$ 로 가장 높았고 5 개월령 거 세가 가장 낮았으며 $(\mathrm{P}<0.05)$, 불포화지방산 중에서 단가불포화지 방산 함량은 거세시기별로 차이는 없었으나 3 개월령 거세가 다소 높았으며 거세가 비거세보다 약간 높은 경향이었다. Werdi Pratiwi 등 (2005)은 호주 Feral goat와 Boer goat에서 지방산 함량은 $\mathrm{C} 18: \ln 9 \quad 43.3 \sim 53.8 \%$ 로 가장 많았고 다음으로 $\mathrm{C} 16: 0 \quad 22.5$ $27.9 \%, \mathrm{C} 18: 0 \quad 10.7 \sim 18.1 \%$ 이었고, 거세는 비거세보다 $\mathrm{C} 18: 0$ 과 $\mathrm{C} 18: 2 \mathrm{n} 6$ 그리고 포화지방산 함량이 낮고 단가불포화지방산의 비율 은 더 높았다고 보고하여 본 시험결과와 비슷하였다.

한편 Madruga 등 (2001)은 브라질 재래염소에서 거세가 비거세 보다 불포화지방산과 다가불포화지방산이 더 높았다고 보고하여 본 시험에서 나타난 다가불포화지방산 함량과 다소 차이가 있었다. 이 러한 지방산조성의 차이는 염소의 품종과 도축시 체중 그리고 거세 와 비거세간의 호르몬의 차이와 밀접한 연관이 있는 것으로 생각된 다.

\section{요 약}

본 시험은 거세시기가 흑염소의 발육, 육질 및 지방산 조성에 미 치는 효과를 구명하기위하여 흑염소 육성축 수컷 45 두를 공시하여 거세시기를 각각 달리하여 2008년 3월 21일부터 2008년 10월 31 일까지 225일간 실시하였으며 그 결과는 다음과 같다.

일당증체량은 거세시기별로 차이는 없었으나 3 개월령과 5 개월령 에 거세한 것이 다소 높은 경향이었고, 비거세가 거세보다 높은 것 으로 나타났다 $(\mathrm{P}<0.05)$. 도체율은 15 일령 거세가 7 개월령 거세보 다 높았고 $(\mathrm{P}<0.05)$, 정육율은 거세시기별로 차이가 없었으나 비거 세가 거세보다 높았다 $(\mathrm{P}<0.05)$. 지방율은 거세시기가 빠를수록 높 았고 거세가 비거세보다 높았다 $(\mathrm{P}<0.05)$. 흑염소고기의 일반조성 분인 수분함량은 거세시기가 빠를수록 감소하는 경향이었고, 조단 백질과 조지방 함량은 거세시기가 빠를수록 증가하는 경향이었다. 육질의 물리적 특성인 전단력, 가열감량 그리고 보수력은 거세시기 별로 차이가 없었으며 관능검사 결과 다즙성과 연도는 5 개월령 거 세가 다소 우수한 경향이었고, 향미는 7 개월령 거세가 15 일령과 3 개월령 거세보다 우수하였다 $(\mathrm{P}<0.05)$. 포화지방산 함량은 5 개월령 거세가 높았고 3 개월령 거세가 낮았다 $(\mathrm{P}<0.05)$. 불포화지방산 함 량은 반대로 3 개월령 거세가 가장 높았고 5 개월령 거세가 낮았으 며 $(\mathrm{P}<0.05)$ 거세와 비거세간에는 차이가 없었다. 단가불포화지방 산 함량은 거세기기별로 차이가 없었으나 3 개월령 거세가 비거세 
보다 높았다 $(\mathrm{P}<0.05)$. 이러한 결과를 종합적으로 고려하면 흑염소 의 발육과 육질 개선에 유리한 거세시기는 3 5개월령이 적정할 것 으로 사료된다.

\section{인 용 문 헌}

Allan, C. J. and Holst, P. J. 1989. Comparison of Growth and Dressing Percent Between Intact Male, Castrated Male and Female Kids of Australian Bush Goats. Small Ruminant Research. 2:63-68

A.O.A.C. 1990. Offical methods analysis. Association of offical analytical chemists. 15th edition. Washington, D.C.

Babiker, S. A., El Khider, I. A. and Shafie, S. A. 1990. Chemical Composition and Quality Attributes of Goat Meat and Lamb. Meat Science. 28:273-277.

Banskalieva, V., Sahlu, T. and Goetsch, A. L. 2000. Fatty acid composition of goat muscles and fat depots: a review. Small Ruminant Research. 37:255-268.

Folch, J, Lees, G, Sloane-Stanley. 1957. A simple method for the isolation and purification of total lipids from animal tissues. $\mathrm{J}$ Biol. Chem. 226:497-509.

Galbraith, H., Demspter, D. G. and Miller, T B. 1978. A note on the effect of castration on the growth performance and concentrations of some blood metabolites and hormones in British Friesjan male cattle. Anim prod. 26:339-342.

Haddad, S. G., Husein, M. Q. and Sweidan, R. W. 2005. Effects of castration on growth performance and carcass characteristics of Awassi lambs fed high concentrate diet. Small Ruminant Research.

Koyuncu, M., Duru, S., Kara Uzun, S., Ozis, S. and Tuncel, E., 2007. Effect of castration on growth and carcass traits in hair goat kids under a semi-intensive system in the south-Marmara region of Turkey. Small Ruminant Research. 72:38-44.

Louca, A., Economides, S. and Hancock, J. 1997. Effects of castration on growth rate, feed conversion efficiency and carcass Quality in Damascus goats. Anim. Prod. 24:387-391.
Morrison, WR and Smith, LM 1967 Preparation of fatty acid methylesters and dimethylacetals from lipid with boron fluoridemethanol. J Lipid Res. 5:600-607.

Madruga, M. S., Arruda, S. G. B. and Nascimento, J. A. 1999. Castration and slaughter age effects on nutritive value of the "Mestico" goat meat. Meat science 52:199-125.

Madruga, M. S., Narain, N., Souza, J. G. and Costa, R. G. 2001. Castration and slaughter age effects on fat components of "Mestico" goat meat. Small Ruminant Research. 42:77-82.

Mahgoup, O., Khan, A. J., Al-Maqbaly, R. S., Al-Sabahi, J. N., Anna-malai, K. and Al-sakry, N. M. 2002. Fatty acid composition of muscle and fat tissues off Omani Jebel Akhdar goats of different sexes and weights. Meat Science. 61:381-387.

SAS. 1991. User's Guide Statistics. Statistical Analysis System Institute Inc. Cary. NC.

Sing, C. N., Saikia, S. and Bruah, D. K. 1996. Effect of method of castration on carcass characteristics of male kids. J. Assam Vet. Coun. 6:33-33.

Tahir, M. A., Al-Jassim, A. F. and Abdulla, A. H. H. 1994. Influence of live weight and castration on distribution of meat, fat and bone in the carcass goats. Small Ruminant Research. 14:219-223.

Tshabalala, P. A., Strydom, P. E., Webb, E. C. and De Kock, H. L. 2003. Meat quality of designated South African indigenous goat and sheep breeds. Meat Science. 65:563-570.

Werdi Pratiwi, N. M., Murray, P. J., Taylor, D. G. and Zhang, D. 2005. Comparison of breed, slaughter weight and castration on fatty acid profiles in the longissimus thoracic muscle from male Boer and Australian feral goats. Small Ruminant Research.

서영석. 1983. 한국재래산양의 거세가 증체 및 도체능력에 미치는 영향. 한 축지. 25(5):456-463.

최순호, 조영무, 김맹중, 채현석, 이지웅, 김영근. 2000. 흑염소의 거세 및 사향선제거가 성장 및 육질에 미치는 영향. 동물자원지. 42(6):891896.

(접수일자 : 2009. 10. 7 / 수정일자 : 2010. 1. 18 / 채택일자 : 2010. 2. 1) 